\title{
Improving Islamich Higher Education: Lessons From John Dewey and Ivan Illich
}

\author{
Muhammad Adib Abdushomad ${ }^{1 *}$ \\ ${ }^{1}$ Ph.D Candidate at Flinders University-Australia \\ Email:adib_gja@yahoo.com
}

\begin{abstract}
Apart from these research are trying to understand, economic and political philosophy, or ideology, underlies approaches that undertaken by government to deliver their services. In relation to the above discussion, this paper aims to elaborate the two thinkers; John Dewey and Ivan Illich to see how Islamic education could meet human needs, particularly to enhance the institutions that enable people to develop their full potentiality. This paper will elaborate the two thinkers' perspectives and bring it into real situation in my department. The first section will capture the debate on education and schooling, includes the aims of education, and also approach to educational policy. Following this, the second section is going to analyses John Dewey and Ivan Illich perspectives on education. Thirdly, reconstruct a new way of thinking based on ideological approaches for the directorate of Islamic Higher education (DOIHE) to find out a better way to address some problems occurs recently.
\end{abstract}

Keywords: Islamic Higher Education, Education and Schooling, Ideological Approaches, Directorate of Islamic Higher Education

\section{A. INTRODUCTION}

One of the key viewpoints of the enlightenment was the belief that all people were equal and had the capacity for reason to pursue their own happiness and life choices. According to Boyd, et.al (2007) "if people were freed from ignorance and dominance by others, and were given equal access to resources such as education, they could better themselves and thus better society" (p.73).

The enlightenment led to the catch-cry of "Liberty, Equality, Fraternity" which became the basis of new belief in the importance of education as the mean to developing thinking, free individuals, which would create greater equality in society. Since, education and reason were considered as importance aspects of an individual's life and also the betterment of society as whole, a lot of research has been conducted to construct a good society through the education (Bell \& Stub, 1968). Apart from these research are trying to understand, economic and political philosophy, or ideology, underlies approaches that undertaken by government to deliver their services (Haralambos, 1996).

\section{B. METHODOLOGY}

This paper aims to elaborate the two thinkers; John Dewey and Ivan Illich to see how Islamic education could meet human needs, particularly to enhance the institutions that enable people to develop their full potentiality. 
Therefore, divided into three sections, this paper will elaborate the two thinkers' perspectives and bring it into real situation in my department. The first section will capture the debate on education and schooling, includes the aims of education, and also approach to educational policy. Following this, the second section is going to analyses John Dewey and Ivan Illich perspectives on education. Thirdly, reconstruct a new way of thinking based on ideological approaches for the directorate of Islamic Higher education (DOIHE) to find out a better way to address some problems occurs recently.

\section{RESULT AND DISCUSSION}

\section{Education and Schooling}

Since the paper will elaborate about educational issue, it is useful to distinguish between education and schooling. Stromquist as cited in William (2004) poses a useful characterization. He argues that education is the transmission of broad and specific knowledge that includes but also goes beyond that imparted by national school system. Education may occur in formal situations, non-formal situations and informal situations. On the other hand, schooling relates specially to the structured and institutionalized type of knowledge transmitted through formal educational institutions, mainly schools and universities. In contrast, non-formal education represents less institutionalized forms of instruction, often program or project-specific, that seeks to impart knowledge, skills, attitude, and behaviours, as well as empowering learners.

Given these explanations, there is different view on education between educator and sociologist. The sociologist perceives the institution of education in a broader sense than the educators. According to Bell and Stub (1968), the educator often places the major emphasis on the formal and structured aspect of education. In contrast, the sociologist defines education to include the formal and informal as well as the structured and unstructured elements. In other word, the sociologist sees education as being almost synonymous with socialisation (p.1). In this respect, sociologist is interested in more than just the formal school system.

Having said that, in my opinion, this framework can be used as a tool to differentiate the way Dewey sees the education and what Illich defines education as the condition for true learning. As a historian with theologian intuition, according to Illich (1971) schooling was so structured as an endless process of escalating ritual that had replaced the true sense of education. Illich's critique of schooling addressed the impact on compulsory education. For him, not only education but social reality itself has become schooled. School has become the world religion of modernized proletariat, and makes futile promises of salvation to the poor of technological age (p.14)

On the other hand, American educationalist, John Dewey, says that school still as democratic places to create a good society in the future. He believes that it was the task of educator and school system to encourage individual to develop their full potential as human beings. (Haralambos, 1996). I will elaborate and give more explanation the tension between the two thinkers in the second section.

\section{Critique the aims of Education}

The power of global economy which emphasis efficiency, market orientation, and direct state control has impact on the design of education (Apple, 2003). Education, --to some extent-has been implemented to meet the need of a restructured economy, rapidly changing labour market and the exponential development of technology and of knowledge. Therefore, it is likely that those 
who can afford to go to schools with the equipment and expertise will be a good deal better off. In such a world, education faces the challenge of being transformed from a system based on industrial model. As the result, getting a degree has now become commonplace. This simply means that education is being increasingly seen as a commodity, as something esteemed because of its 'exchange value' on the market, rather than its 'use-value' as something good in its own right and for its own sake (Boyd, 2007).

With the social changes and challenges to traditions that came in the 1960s (such as peace the peace movement, the civil right movement, etc) many began to question the aim and methods of education. Many social and educational reformers came to believe that far from freeing up individual from their social background (class, gender, ethnic and sexuality), they are questioning 'What is education for'? Particularly in today globalised world. In relation to this, Noddings (2003) challenges his view;

It is as though our society has simply decided that the purposes of schooling is -economic-to improve the financial condition of individuals and to advance prosperity of the nation. Hence student should do well on standardized test, get into good colleges, obtain well paying jobs, and buy a lot of things. Surely there is more education than this (p.4)

Nodding's reflection also supported by American Sociologist Talcott Parsons. As modern industrial society is increasingly based on achievement rather than ascription, Parson saw that the education has become an important mechanism for the selection of individuals for their future role in society. Therefore, he argues that the school represent "society in miniature" (Haralambos, 1996, p.210). As it can be seen on the nature of schools which emphasize on testing and evaluating student, match their talents, skills and capacities to the jobs for which they are best suited.

Like Parson, David and Moore (as cited in Haralmbos, 1996) saw education as a mean of role allocation, but they linked the education system more directly with the system of social stratification. High reward which act as incentives are attached to those positions and this means, in theory, that all will compete for them and the most talented will win through.

Another challenges faces in the field of education are the idea that the education should aim at creating a more equal and just society. Willis (1977) discovered how poorer children often grow up in environments where people see little hope of upward mobility and rebel against the system rather than trying to conform to it. Therefore, the aim of education according to him should be to counter social inequality and build more just society by educating everyone according to what knowledge they needed to succeed, rather than through some blanket universal program.

While it is true that behind all educational proposals are visions of a just society and a good student, it is interesting to note that the tensions among ideology still occur in the current educational policy. According Apple (2003) states that the most powerful group within the new alliance are neoliberals and neoconservatives, and the reform they tend to propose the just society and the good student in particular way.

For the purpose of this paper I would like to limit my paper on liberal point of view particularly to elaborate John Dewey and Illich. 


\section{Liberal perspectives:}

\section{a. John Dewey and Ivan Illich}

According to Heywood (1992), the main characteristic themes of liberalism ideology are the belief on individualism. Liberal is united in their desire to create a society in which each individual is capable of the developing their full potentiality. Historically, liberal ideas resulted from the breakdown of feudalism in Europe and the growth of a market or capitalist society.

There are many categories of liberal worldview. Firstly, classic liberal is based upon the idea of sovereignty; it assumes an autonomous, we know the best, self-ruling and self-fulfilling entity. Secondly, modern liberal is based upon assumption that individual freedom needs government to enable individual to pursue their own freedom (Heywood, 1992). However, in the reality there is always tension between the two approaches. Nowadays, with the movement toward economic rationalism, there was the focus more back to the individual. Therefore, the individual will get an extra reward, salaries and other attentions. So the focus became on the individual, and also the movement backs in forward, in term of collective and individual. So in this regard, there is continuity and change, particularly to think about individual and collective back in forward. Heywood called this phenomenon as neo liberalism or economic rationalism and Haralambos categorized as new economist. Just puts the same thing, because this is only a description of the same historical phenomena.

According to liberal viewpoint the main purpose of education is held to be the promotion of wellbeing of the individual, and only indirectly the improvement of the society. Generally, liberal hopes that education will help to reduce inequality. Although, liberal acknowledge that there is a need for reform, they believe that with relatively minor modifications education can come to play a full and successful role in industrial societies (Haralambos, 1996).

One of the most influential proponents of liberal view in education was the American educationalist John Dewey. Dewey was born on October 20, 1859 in Burlington, Vermont. His father, Archibald Sprague, a North Grocer and later a tobacconists, was a handsome, outgoing, and witty man (Neil 1973). He argues that it was the job of education to encourage individual to develop their full potential as human beings. He particularly stressed the development of intellectual potential. Schooling for all would help to foster the physical, emotional and spiritual talents of everyone, as well as their intellectual abilities (Haralambos, 1996).

According to George (1958), Dewey influence in education is seen as something like; learning by doing, the child-cantered school; interest and effort, permissiveness. In this regards, Dewey propose to consider the context and the function of philosophy as a living culture, and it is the task for philosophy to criticize, clarify, test the internal coherence, and make explicit the consequences of the beliefs, custom and social institution, such as education.

Dewey has made a complete integration of his work in philosophy, psychology, and practical pedagogy as chairman of the philosophy and education department at the University of Chicago (Dykhuizen, 1973). Bertrand Russel (1945) in his book 'History of Western Philosophy' give further comment about Dewey;

He is a man of a highest character, liberal in outlook, generous and kind in personal relations, indefatigable in work. With most of his opinions I am almost complete agreement. Owing to my respect and admiration for him, as well as to personal experience of his kindness, I should wish to 
agree completely, but my regret I am compelled to dissent from his most distinctive philosophical doctrine, namely the substitution of 'inquiry' for truth as the fundamental concept of logic and theory of knowledge (p.819).

Education is to be defined in Dewey's term as philosophy in action, therefore, the study of philosophical questions must arise naturally from the experience of students and teachers with their own education. In line with this statement, according to Dewey (Dykhuizen, 1973) the aim of all education was to develop a body of knowledge and a philosophy with which to deal with whatever comes up in one's life, to make oneself an instrument of continuous learning. In other words, education is "a living laboratory" in which philosophic distinction become concrete and is tested (Ann, 1970). Dewey also suggest that there must be complete freedom of scientific inquiry into social problems, the resulting knowledge must be disseminated among the people, full publicity must be given to plan and policies currently in operation (p.19).

Dewey often used the term "education" in a normative sense. For Dewey, not every modification of experience or behaviour is to be considered educative, infact, it can be said as miss-educative. In his most reprinted article "My pedagogic Creed" (1897 as cited in Ann, 1970) the school he says is primarily a social institution. Education being a social process, the school is simply that form of community life in which all those agencies are concentrated that will be most effective in bringing the child to share in the inherited resources of the race and to use his own powers for social ends. This is again, is a normative statement; Dewey is manifestly that the school should be such institution.

The school is for Dewey one of the main engines of progress, democracy, and growth (p.263). Therefore the school must help the individual in a multitude of ways, by developing intellectual power, moral responsibility, aesthetic sensitivity, practical day-to-day competence.

It is true that Dewey has intense focus on the individual, but he also has an interest about social as well and says that school as democratic place to develop human well being and moral knowledge (Hansen, 2007). Therefore, Dewey called himself as social democrats, not as liberal (Banfield, 2008). In contrast, Illich argue that the education system as the root of the problems of modern industrial society. Schools are the first, most vital and important stage in the creation of mindless, conforming and easily manipulated citizen. He further advocates de-schooling society (Illich, 1971). He points out that there is no reason why it should be accepted as somehow inevitable. Since schools do not promote equality or the development of individual creative abilities, why not do away with them in their current form? More explanation about Illich can be seen on the next section.

\section{b. Ivan Illich}

One of the most controversial recent writers on educational theory is Ivan Illich (Wright, 2003). In his book 'Celeberation of Awareness' Illich noted for his criticism of modern economic development, which he describes as a process whereby previously self-sufficient peoples are dispossessed of their traditional skills, and made to rely on doctors for their health, teacher for their schooling, television for their entertainment (1977).

Ivan Illich differed from the convention liberal. According to him formal schooling is unnecessary, and ideed harmful to society (Haralambos, 1996). Illich begun with his views on what education should be (Aquilera, 2008). First, there is the learning of specific skills, such as typing, woodwork and speaking a foreign language. Next, there is education itself, which is not concerned with the 
acquisition of particular skills. Education should be liberating experience in which individual explore, create, use their initiative and judgement and freely develop their faculties and talent to the full.

Illich main attack was on the failure of schools to match his educational ideals. He regarded schools as repressive institutions, which indoctrinate pupils, smother creativity and imagination, induce conformity and stultify student into accepting the interests of the powerful (Haralambos, 1996).

Students become dependent on the directives of governments, bureaucratic organisations and professional bodies. Illich proposed a simple yet radical solution. As the title of his book 'deschooling society' suggest the answer lies in the abolition of the present system of education. What school should do according to Illich is skill exchanges, in which instructors teach to others the skills they use in daily life. Illich argued that skills could best learned by drills involving systemic instruction. More importantly Illich proposed 'learning web' which consist of individuals with similar interest who meet around a problem chosen and defined by their own initiative and proceed on a basis of creative and exploratory learning (Illich, 1971).

Schools are even less efficient in the arrangement of the circumstances, which encourage the open-ended, exploratory use of acquired skills, for which I will reserve the term "liberal education". The main reason for this is that school obligatory and becomes schooling for schooling sake: an enforced stay in the company of teachers, which pays off in the doubtful privilege (Haralambos, 1996).

Just as skills instruction must be freed from curricular restraints, so must liberal education be dissociated from obligatory attendance? Both skill-learning and education for inventive and creative behaviour can be aided by institutional arrangement, but they are of a different, frequently opposed nature. (Illich, 1971, p.25)

Based on the above explanation, to improve the aims of education Illich suggest something to choose, either we continue to believe that institutionalized learning is a product which justifies unlimited investment or we rediscover that legislation and planning and investment, if they have any place in formal education, should be use mostly to tear down that barriers that now impede opportunities for learning, which can only be a personal activity not only to seek for certificate (p.72). This is dominant type in which Illich propose as the "manipulative institution" (p.76).

To be a good educational system according to Illich (1971), system should have three purposes: it should provide all who want to learn with access to available resources at any time in their lives. Secondly, empower all who want to share what they know to find those who want to learn it from them, and lastly furnish all who want to present an issue to the public with the opportunity to make their challenge known. Schools are not the only institution, which distorts profession by packaging roles.

Erich Fomm classified Illich as Humanistic radicalism which means capacity for critical questioning of all assumptions and institutions which have become 'idol' under the name of common sense, logic, and what is supposed to be natural (Calder \& Boyar 1972).

Humanistic radicalism according Fromm as cited in Calder \& Boyar 1972), is radical questioning guided by insight into dynamics of man's nature; and by concern for man's growth and full 
unfolding. In this regards, Illich papers deal precisely with such examples as the usefulness of compulsive schooling with imaginative aspect. Erich Fromm comment about Illich:

"The author is man of rare courage, great aliveness, extraordinary erudition and brilliance, and fertile imaginativeness. The importance of his thought in this as well as his other writings lies in the fact that they have a liberating effect on the mind by showing entirely new possibilities, they make the reader more alive because they open the door that leads out of the prison of routinised, sterile, preconceived notions. By the creative shock they communicate, they help to stimulate energy and hope for a new beginning (p.10).

Illich further suggest that we can escape from dehumanizing system. Our freedom and power are determined by our willingness to accept responsibility for the future. We must abandon our attempt to solve our problem through shifting power balances or attempting to create more efficient bureaucratic machine.

Schooling also involves a process of accepted "ritual certificate" for all members of a school society. Schools select those who are bound to succeed and send them on their way with badge marking them fit. Once universal schooling has been accepted as the hallmark for the in member of society.

We must not exclude the possibility that the emerging nations cannot be schooled, that schooling is not viable answer to their need for universal education. For some generations, education has been based on massive schooling just as security was based on massive retaliation and school become untouchable because they are vital to the status-quo. (p.112)

According to Illich, people at the moment has adopted "a new religion". Its doctrine is that education is a product of school, a product that can be defined by numbers. There are the numbers which indicate how many years a student has spent under the tutelage of teachers, and others which represent the proportion of his correct answer. Furthermore, as the impact of schooling process, the power of certification has grown so rapidly (Illich, 1971).

The school has become the established church of secular times. The modern school had its origin in the impulse toward universal schooling, as attempt to incorporate everyone into the industrial state. In the industrial metropolis the school was the integrating institution (Wright, 2003).

John Dewey who concern on philosophy and education claims that the true centre of learning was not the realm traditional subject (classical), but in child own social (useful) activities (Hansen, 2007). As the father of progressive education, Dewey argues that both elementary and high schools must move closer to the learner's life experience and away from accepted dogma and absolute knowledge. Learning Dewey wrote, is active it, involves reaching out of the mind (Hodges, 1974).

School, according Hodges, ironically have defaulted on one of the more valid if rarely practiced of John Dewey ideals: "Children should have voice in determining both the curriculum and the rules of their school. Democracy is best learned by living it"(p.401).

As the result school tend to be passive rather than active partners, guardian of tradition rather than initiator of change, dependent rather than independent variables. The school is subsystem of the larger social system. Most of the processes and structures of the school are simply mirrors 
reflecting, imperfecting, present or past images of the larger society. (Cayo Sexton, p.2 as cited in Hodges 1974)

According to Dewey, for education aim to be concrete it must meet a number of criteria. First, it must be relevant to the individual's particular experience; that is to say it must be an aim in the individual's experience and education. Secondly, the aim must be flexible, able to guide activity but also able to be modified by activity. Thirdly, the aim must function to liberate or free action in planned sequence, (Dewey, 1916)

On the other hand, Ivan Illich questioning 'How autonomous is the school, particularly in today post industrial society? The reality is that, the very closeness of fit between the school and the allocation of occupational rules means that it is virtually impossible for the school to act independently. Therefore, Illich advocates de-schooling society (Illich, 1971).

Offcourse Illich does not mean by this that all form of educational organisation should be abolished (Giddens, 1989). This view is supported by Aguielera (2003), He said that Illich do not object the existence of school as such, as long as they were recognized as privileged enclave and do not monopolize public choices. In line with this, Illich argues that education, should provide everyone who wants to learn with access to available resources-at any time in their lives, not just in their childhood or adolescent years. Such a system should make it possible for knowledge to be widely diffused and share, not confined to specialist. Learners should not have to submit to a standard curriculum, and they should have personal choice over what they study (Illich, 1971, p.108).

In place of school however, illich suggest several types of educational framework. Material resources for formal learning would be stored in libraries, rental agencies, laboratories and information, storage bank available to any student. Communication network would be set up providing data about the skills possessed by different individuals and whether they would be willing to train others, or engage in mutual learning.

Although both Dewey and Illich can be described as liberal in the way much more emphasizes on individual; they are completely different in their thinking about schooling. Ivan Illich for instance says that the big problem is the structures of schooling. He further argues that we need to change the character of school as "liberal education" (p.25). He really believes that people will learn as they need to learn through experience, instead learning through the book and school systems.

As I explained earlier that John Dewey still believe that institution of education is an important place to promote democracy, intellectual development, and also individual well beings. As a philosophy in education, he is aware about the limitation of institution (education) if it is not delivered properly. Therefore, to some extent, Dewey can be classified as social-democrat, saying that a good society is where we looking after each other to share area of concern, such as democracy, intellectuality and also social justice. Illich, on the other hand, want to give 'early warning system' the negative effect of education that has been schooled and structured. However, it does not mean that he want to abolish all the education system. Probably its only his choice of word in which sometimes hyperbolic and provocative (Cox, 2002).

\section{A Reflection for the Directorate of Islamic Higher Education (DOIHE)}

Nowadays, the Directorate of Islamic Higher Education (DOIHE) is confronting with some private and public universities who give an opportunity to offer a degree without formal meeting in class, appropriately. As the result, people tend to have certificate oriented, rather than considering the 
quality of education itself (Mas'ud, 2007). This is because; the degree (certificate) has become bargaining position to increase their status in society and also in their office to get a certain job. In this respect, the mission of Islamic university or schooling has failed to create the qualified graduates.

In relation to the above explanation between the two thinkers John Dewey and Ivan Illich, I would like to elaborate some key points. Firstly, the early warning given by Ivan Illich, saying that we need to avoid education with emphasis on packaging instruction with certification too much (Illich, 1971). According to Azizy (2004) Islamic education should build body of knowledge within its education system. Citing Whithead (1957), Azizy, the former director general of Islamic education, agued that "a progressive society depend upon its inclusion of three groups; scholar, discovers, and inventors" (p.109). In relation to this, Islamic education needs to liberate the institution becoming 'enlightening institution' not as manipulative institution which only gives a grade and certificate. The certificate should reflect at least basic competence of what they have learnt. To do so, the content or the curriculum should be designed to promote problem solving in real life and continuous learning. This view is supported by Bok (1986), the former president of Harvard University. He said that "education no longer be content with teaching students to remember fixed body of knowledge; instead we must help them to master techniques of problem-solving and habits of life long learning" (p.5) .

Secondly, it is the responsibility of Islamic higher education to give support for Islamic institution to raise their quality, particularly to promote equality access of education. Citing Bernard Bailiyn (1972), I believe that no educational activity could be entirely "private' for none was legitimately independent of the state.

\section{CONCLUSION}

Both Dewey and Illich are concerned with reform within the framework of existing social institutions. Illich advocates radical change with his idea 'de-schooling society'. In contrast Dewey, suggest a reform of existing institutions rather than saying that the system is completely wrong. This because, many sociologists appeared to viewpoint that education was good thing and that reforms in the education system would lead to progressive social change in society as well, even though far from perfect.

The directorate of Islamic Higher Education need to consider their policy particularly to promote two things at the same time. To give student a good education facilities to develop their own potentiality and try to understand what happen inside and outside of in Islamic education, in term of teachers, students, etc. 


\section{References}

Ann (1970). Guide to the works of John Dewey, Southern Illinios University Press, USA.

Apple M.W., (2001). The Rhetoric and Reality of Standard-Based School Reform, Educational

Policy, Vol. 15 No. 4, September. Retrieved November 26, 2008, from http://epx.sagepub.com

Azizy Qodry (2004). Pengembangan IImu-IImu Kelslaman, Aneka Ilmu Semarang, Indonesia

Bailyn Bernard (1972). Education in the forming of American society, W.W. Norton Company, Inc., New York.

Banfield Grant (2008). Construction of Education and Social Justice, Personal recorded material, The School of education, Flinders University. SA

Bell \& Stub (1968). The sociology of education; A source book, The Dorsey Press, Irwin-Dorsey Limited, Illinois, USA.

Bernstein R. (1960). Dewey; on experience, Nature and Freedom, The Library of liberal art, The Boss Merril, Company Inc. New York.

Box Derek (1986). Higher learning, Harvard University Press, Cambridge.

Boyd, Wadham, Pudsey \& (2007). Culture and Education, Pearson, Education Australia.

Boyars \& Calder (1972). Celebration of Awareness, Latimer Trend Co.Ltd, Great Britain.

Coughlan Neil (1973). Young John Dewey; An essay in American Intellectual History, The university of Chicago Press.

Cox Halsey (2002). A Prophet, A teacher, A Realistic Dream, National Catholic Reporter, (20).

Dykhuizen, G (1973). The life and mind of John Dewey, Southern Illinois University Press, Feffer \& Simons, Inc, USA.

George (1958). John Dewey in perspective, New York Oxford Press University.

Giddens Anthony (1990). Sociology, Polity Press, Cambridge, UK

Hansen (2007). John Dewey and Curriculum of Moral Knowledge, Curricullum and Teaching Dialogue, No 172, p.173-181

Haralambos, Krieken, Smith, Horborn (1996). Sociology; themes and perspectives Australian edition, Longman, Australia.

Heywood, A. (1992). Political Ideologies; An Introduction. Houndmillis, Mcmillan.

Hodges, Jr. ( 1974). Conflict and consensus : An introduction to sociology, second edition, Harper \& Row, Publisher, New York, USA. 
Illich (1970). Deschooling Society, Harrow Books, Harper and Row, New York, USA Illich (1972). Celebration of Awareness, A call for institutional revolution, Great Brittain. Illich (1977). Disabling Professions, Marion Boyars Publishers Ltd. 18 Brewer Street London. Mas'ud (2007). Pendidikan Non-dikotomik, Gama Media Press, Yogyakarta. Noddings (2003). Happiness and education, Cambridge University Press, Cambridge. Reimer Everett (1972). School is dead, Double Day Garden City, New York. Russel (1945). History of Western Philosophy, New York Whithead (1957). The aims of education and other essays, The Free Press, New York.

William, J (2004). Civil Conflict, Education, and the Work of Schools: Twelve Prpopositions, Wiley Periodicals Inc.

Willis (1977) Learning to Labour. Saxon House, Farnbourough Wright (2003). Obituary of Illich, Lancet, Vol. 361. 